\title{
Hellige bygninger på grænsefladen i dansk kommunalpolitik
}

\author{
BRIAN ARLY JACOBSEN
}

ENGLISH ABSTRACT: Physical space is challenged on the basis of aesthetic, ideological, religious, environmental and economic perspectives. Buildings and structures play a prominent role in the competition for recognition between social groups. Especially church structures have historically represented a city's vision for dynamic growth, status, and innovation. With migration and new religious movements' establishment in Denmark, the need for new sacred buildings has been significant. In the article I analyze the attempts to establish religious buildings in public space in Denmark by two different religious groups. Both attempts ended in conflict with the surrounding society. In both cases, the local council's option of using the Planning Act to develop a local development plan plays an important role for the possibility of religious organizations to build, for the building location as well as the building's appearance within the Danish model of religion.

DANSK RESUMÉ: Fysiske rum anfægtes ud fra æstetiske, ideologiske, religiøse, miljømæssige og økonomiske perspektiver. Bygninger og bygningsværker spiller en fremtrædende rolle i konkurrencen om anerkendelse mellem sociale grupper. Historisk har især kirkekonstruktioner repræsenteret en vision for dynamisk vækst, status og for innovation. Med migration og nye religiøse bevxgelsers etablering i Danmark er behovet for nye hellige bygninger blevet signifikant. Artiklen analyserer to cases, hvori to religiøse gruppers forsøg på at etablere religiøse bygninger $i$ det offentlige rum $i$ Danmark er endt $i$ konflikt med det omgivende samfund. I begge sager spiller planlovens muligheder for en kommunalbestyrelse til at udarbejde lokalplaner en vigtig rolle for de religiøse organisationers mulighed for inden for den danske religionsmodel at bygge, for byggeriets placering samt for byggeriets udseende.

KEYWORDS: Holy building; mosque; local politics; Sai Baba; building plan 
Grænsefladerne i den danske religionsmodel bliver afmærket ved hjælp af en række politiske redskaber. En af de mere ubemærkede er kommunalbestyrelsernes mulighed for at regulere byggeri via lokalplaner. Lokalplaner er et vigtigt lokalpolitisk redskab, der bestemmer bygningsmiljøet i Danmark. Det gælder også for trossamfunds muligheder for at planlægge og etablere religiøse bygninger, og traditionerne for religiøse bygninger harmonerer ikke nødvendigvis med en vedtaget lokalplanspolitik. Lokalplaner skal ifølge Lov om planlægning (2013) udarbejdes for alle anlæg som enten på grund af deres størrelse eller af andre grunde skønnes at ville medføre væsentlige ændringer i det bestående miljø. Allerede her eksisterer der muligheder for udøvelse af et politisk skøn, nemlig hvorvidt en lokalplan er lovpligtig og skal gøres gældende i forhold til et planlagt byggeri eller ej. Hermed eksisterer der også et potentiale for konflikt. Religionsmodellens grænseflader bliver således klarlagt, ved accepten eller forkastelsen af etableringen af hellige bygninger.

I denne artikel vil jeg analysere to cases, hvor forskellige religiøse gruppers forsøg på at etablere religiøse bygninger i det offentlige rum i Danmark er endt i konflikt med det omgivende samfund. I begge sager spiller planlovens muligheder for en kommunalbestyrelse til at udarbejde lokalplaner en vigtig rolle for de religiøse organisationers mulighed for at bygge, for byggeriets placering samt for byggeriets udseende. En lokalplan giver kommunen ansvaret for at styre den fremtidige udvikling i et område og giver borgerne og byrådet mulighed for at vurdere konkrete tiltag i sammenhæng med planlægningen som helhed. Planloven bestemmer, at byrådet har pligt til at lave lokalplan, før der gennemføres større udstykninger eller større bygge- og anlægsarbejder, herunder udformning af byggeri. Når byrådet har vedtaget lokalplanen endeligt og bekendtgjort den offentligt, er den bindende for de ejendomme, der ligger inden for lokalplanens område. ${ }^{1}$ Hvorvidt offentligheden skal inddrages eller ej, når lokalplanen skal udarbejdes, er kommunalbestyrelsens vurdering. Planlovens bestemmelser om offentlighed er et eksempel på skønsprincippets anvendelse i lokalpolitikken. Heri står der blandt andet "at offentligheden i videst muligt omfang inddrages" (§ l, stk. 5). For lokalplaner er der stramme offentlighedsregler, men hvorvidt et projekt er så omfattende, at der skal laves lokalplaner beror i en vis udstrækning på kommunalbestyrelsens skøn. I de to cases, som analyseres her, har kommunalbestyrelserne vurderet, at der var behov for en lokalplan, men formålet med lokalplansvedtagelserne har, som vi skal se, haft forskellige udgange for de to religiøse organisationers muligheder for at etablere sig i et lokalområde.

\section{Religionsfrihed og hellige bygninger}

Det er først og fremmest folkekirken, som har præget det religiøse bygningslandskab i Danmark, men også andre religiøse samfund har sat sit præg på det religiøse byg-

1 Jf. Bekendtgørelse af lov om planlægning af 2013. 
ningsmiljø. I Danmark har det siden grundlovens indførelse i 1849 været muligt for religiøse samfund at organisere sig og udøve deres religiøse praksis frit, hvis ikke det strider mod "sædeligheden eller den offentlige orden" (Grundloven (1953) § 67). Det er denne paragraf, som sikrer religionsfrihed i Danmark. Med til religionsfrihed hører religionsudøvelse og dermed retten til bygninger at udøve religionen i. Alligevel er minoritetsreligioners byggeprojekter i f.eks. landdistrikter, forstæder eller byområder ofte forbundet med konflikt. Især muslimske gruppers mosképlaner har været og er i fokus, men også andre trossamfund er udsat for offentlighedens kritiske blik. Der findes ca. 140 moskéer i Danmark, typisk i lokaler, der oprindeligt har været bygget til andre formål såsom kontor-, lager- og fabrikslokaler. ${ }^{2}$ Men kun enkelte af disse moskéer har ydre, synlige kendetegn som viser, at denne bygning er et helligsted for muslimer. Andre religiøse minoriteter har etableret synligt religiøse bygninger f.eks. katolske, ortodokse, reformerte og baptistiske kirker og synagoger. Religiøse symboler - herunder religiøse bygninger - har betydning i den offentlige debat og fører regelmæssigt til kontroverser.

De første kontroverser om et moskébyggeri i Danmark var i 1981, hvor Folketinget diskuterede planer for at bygge en moské i Njalsgade på Amager (Jacobsen 2008, 212-219). Samme sag gav også anledning til hed debat i 1991 og 2001. Siden 1992 har lokalplanen for området muliggjort byggeri af en moske på grunden. Byggeriet har dog ligget stille på grund af manglende finansiering, som besværliggøres af opdelingerne i det danske muslimske miljø ud fra etniske, religiøse og politiske forskelle. Historien om den ikke-eksisterende moské på Njalsgade i København er karakteristisk for de debatter, der dukker op over hele landet, når muslimske organisationer præsenterer nye moskébyggeplaner (Jacobsen 2011). En undersøgelse af, hvordan en sådan konflikt udspiller sig kan afsløre betydningsfulde mønstre og processer i de forhandlinger, som religiøse grupper må føre, i bestræbelserne på at etablere religiøse institutioner i det danske samfund. Samtidig er religiøse minoriteters muligheder for at etablere religiøse bygninger en lakmustest på, hvor grænserne for den danske religionsmodel går.

\section{Bygningsværker som anerkendelsespolitik}

Bygninger og bygningsværker spiller en fremtrædende rolle i konkurrencen om anerkendelse mellem minoritets- og majoritetsgrupper. Nogle lokalpolitikere hilser unikke bygningsværker velkommen. Det kan f.eks. være koncertsale, hoteller eller biblioteker. Sådanne nye prominente og ekstraordinære bygninger er normalt meget synlige. Arkitektonisk dominerer de det urbane offentlige rum og har dermed mulighed for at give både bygherrer og byen anseelse. Historisk har det især været kir-

2 Religionssociolog Lene Kühle fandt i 2006 frem til at antallet af moskéer i Danmark var 115 (Kühle 2006, 66). I 2014 vurderede hun antallet til at være op mod 140, jf. “OVERBLIK. Hvad laver muslimer i en moské?" $d r . d k, 19$. juni 2014 
ker, som har repræsenteret en bys vision for dynamisk vækst, status og innovation. Med migration og nye religiøse bevægelsers etablering i Danmark er der kommet et behov for nye hellige bygninger. De to cases analyseret i denne artikel er sagen om Dansk Islamisk Råds moskébyggeri på Nørrebro fra 2012-14 og en Sai-Baba højskole med religiøst center, som aldrig blev realiseret på Arresødal i Frederiksværk i 200102. Analysen af de to cases viser, hvor svært det er at ændre den religiøse topografi, og hvordan kontroverser over religiøse minoriteters hellige bygninger er med til at markere grænsefladerne i og for den danske religionsmodel på et lokalt plan. Det principielle spørgsmål er, hvorvidt religiøse minoriteter har frihed til at bygge deres hellige bygninger. Det er gennem analysen af byggesager i relation til religiøse bygninger, at vi kan se, hvordan grænsefladerne for den danske religionsmodel udfolder sig i praksis.

\section{Danmarks religiøse topografi}

Folkekirken materialiserer sig med kirkebygninger over hele landet. Det er så naturlig en del af den danske religiøse topografi, at kirkebygningen indgår som ikonografisk symbol i landets officielle byskilte. ${ }^{3}$ Danmark består af en fintmasket sognestruktur, der i sin oprindelige form går tilbage til Svend Estridsen (1019-1074). Hans tanke var, at der ikke måtte findes en plet af Danmarks jord, som ikke var en del af et kirkeligt sogn med ret til kirkelig betjening i sognets kirke (Fenger 1989, 106). Indtil kommunalreformen i 1970 var kommunerne i høj grad sammenfaldende med sognestrukturen. Kommunalreformen i 1970 ændrede dette forhold og antallet af kommuner faldt fra ca. 1.300 sognekommuner og 86 købstadskommuner til 273 primærkommuner (Christoffersen 1998, 178-79). Fra 1. januar 2007 mindskede strukturreformen antallet af kommuner igen, nu til 98 kommuner. Antallet af sogne var 2.123 pr. 1 . januar 2013 med i alt 2.354 kirker (Danmarks Statistik 2014). Der er altså ikke et tilnærmelsesvis sammenfald mellem sognestruktur og kommuner i Danmark i dag. Strukturreformens konsekvenser for samarbejdet mellem folkekirke og det offentlige er først ved at vise sig nu, eksempelvis i form af diskussioner om konfirmationsundervisningens placering i folkeskolen (Jacobsen \& Willadsen 2013).

Efter reformationen overtog den evangelisk-lutherske kirke den tidligere sognestruktur samt kirkegods i Danmark og forvaltede den ud fra princippet om, at den danske topografi skulle være dækket af kirker. Statsmagt og kirke har i en årtusindlang periode været forenet $\mathrm{i}$ en ambition om at kristne det danske land og folk, og et af de væsentligste elementer i denne kristningsproces var og er materialiseringen af kristne bygninger. Kirkebygningerne var symbol på stats- og kirkemagt, men også et samlingssted for de kristne tilhøreres religiøse praksis, følelser og udtryk og var dermed med til at forme disse.

3 Marie Vejrup Nielsen gjorde opmærksom på byskiltenes symbolik i sit foredrag ved konferencen Den danske religionsmodels grænseflade på Københavns Universitet 9. oktober 2013. 


\section{Bygningens materialitet $i$ et teoretisk perspektiv}

Materialitet er på en og samme tid en materiel eksistens og politisk konstruktion, som antropologen Birgit Meyer og sociologen Dick Houtman skriver: "Given that materiality is organized through form, one should focus on how processes of social and political formation create a tangible, material world" (Meyer \& Houtman 2012, 6). Sociokulturelle konstruktioner som eksempelvis kirker skal altså forstås som en verdensskabende praksis, der udtrykker den politiske og religiøse magt konkret og fysisk. Ved at gøre materialitet og materiel kultur til centrale begreber i studiet af religion kan man generere andre empiriske spørgsmål om, hvordan religion former verden helt konkret. 'Den materielle vending' har i dette perspektiv en dobbelt betydning. ${ }^{4}$ For det første er det et studie af hellige bygningers betydning for et religiøst samfund i en lokal kontekst, dvs. hvilke implikationer har en eventuel ændring af den religiøse topografi for den religiøse gruppe og for lokalbefolkningen. For det andet er det et studie af 'den hellige bygnings' materialisering i den danske religionsmodels grænseflade, dvs. hvordan bliver det religiøse samfunds hellige sted gjort muligt (eller ej) som sociokulturel konstruktion i den danske religionsmodel.

Den tyske religionssociolog Martin Baumann har udviklet en hypotese om offentlige steder som metaforiske steder (Baumann 2009). Det offentlige rum analyseres som et metaforisk sted, som er indskrevet med meninger og betydninger defineret af sociale grupper. Det offentlige rum er dermed ikke et neutralt sted, det er derimod et udtryk for (i dette tilfælde religiøse) gruppers vundne rettigheder og eventuelle krav fra konkurrerende sociale grupper. Kristne kirker og tårnes hidtil ubestridte monopol på at dominere det offentlige rum er der blevet sat spørgsmålstegn ved på grund af den fremspirende pluralitet af religioner i Europa, primært som resultat af immigration. Sociale processer såsom differentiering, magt, ulighed eller kollektiv handling sker, ifølge den hollandske arkitekt John Habraken, gennem de materielle former, som vi designer, bruger og markerer (Habraken 1998, 226-227). Steder er, kort fortalt, fyldt op med mennesker, praksis, objekter og repræsentationer. I overensstemmelse med det analytiske perspektiv på offentlige rum, har nye semantiske spillere, dvs. nye religiøse grupper i Danmark, krævet rettigheder til deltagelse, mens andre politiske grupper har afvist en sådan ret til adgang. I det følgende vil jeg beskrive forløbet $\mathrm{i}$ de to cases og afslutningsvis diskutere, hvilken betydning den topografiske tilgang har for studiet af helligsteder.

4 Brugen af rumlige metaforer som analytiske begreber har medført, at der tales om en ny vending human- og samfundsvidenskaberne; en såkaldt 'topografisk' eller 'materiel vending' (Østergaard 2006). Begrebet religiøs topografi er inspireret af antropologen Kirsten Hastrups teori om 'den topografiske vending'. Topografiske metaforer illustrerer, at menneske og kultur altid er placeret i et landskab, et landskab der ikke kan og ikke skal tænkes bort. 


\section{Omstridte hellige bygninger}

Konflikter over planlægning og konstruktion af hellige bygninger er et fænomen, som udspiller sig over hele Europa, og har gjort det i årtier (Cesari 2005, 1015-1024). Eksempelvis sagen om moskébyggeriet i den italienske by Lodi i Lombardiet fra 2000. Her blev et planlagt byggeri stoppet som følge af lokal modstand, der involverede demonstrationer, underskriftindsamlinger og symbolsk forurening af moskébyggegrunden med svineblod. Ifølge islamforskerne Chantal Saint-Blancat og Ottavia Schmidt di Friedberg er sagen blevet det italienske svar på, hvad tørklædet symboliserer i fransk politik (Saint-Blancat \& Friedberg 2005, 1083-1104). Ifølge den tyske islamforsker Matthias Rohe, gør samme mønster sig gældende i moskébyggesager i Køln, Berlin, Frankfurt og München, hvor moskébyggerier- og planer har medført protester fra en atypisk koalition af stærkt højreorienterede, små grupper af kristne fundamentalister og tidligere venstreorienterede personligheder (Rohe 2012, 252). Rohe konkluderer, at i den offentlige debat har disse sager erstattet det muslimske tørklæde som det centrale stridspunkt i konflikter mellem muslimer og forskellige andre grupper i det tyske samfund. Konflikter over moskébyggerier i andre europæiske byer viser, at det sjældent kun handler om byggetilladelser, når muslimer vil bygge moskéer. ${ }^{5}$

Der har været voldsomme diskussioner om byggeplanerne for en moské på Njalsgade, siden Forsvarsministeriet underskrev en lejeaftale om grunden med den Ærværdige Islamiske Komité i 1981, og det samme konfliktmønster har vi set med moskébyggeplaner i Aarhus, på Nørrebro og Haderslev (Jacobsen 2009; 2011). ${ }^{6}$ Der var fra regeringens side i 1981 en erkendelse af, at migrantarbejderne skulle have mulighed for at etablere et helligsted, og de fik en statslig aftale om billig leje af en central grund i København (Jacobsen 2011). Den første lokalplan for området indeholdt en plan for et moskébyggeri og ved høringen medførte det næsten 250 indsigelser (ibid., 48). Det var det højeste antal indsigelser, kommunen indtil da havde modtaget i en lokalplanhøringsrunde, for normalt lå lokalplansindsigelser på 10-15 stk. ${ }^{7}$ En underskriftsindsamling blev arrangeret mod opførelsen af en moské, og mere end 6000 skrev under ifølge Berlingske Tidende (21. juli 1991). Aviserne modtog generelt mange læserbreve om moskébyggeriet, og politikerne diskuterede byggeriet offentligt. På trods af protesterne valgte Borgerrepræsentationen i 1992 med et stort flertal at vedtage en lokalplan, som reserverede grunden på Njalsgade til byggeriet af en moské (Jacobsen 2011). Hærværk mod moskéer eller moskébyggegrunde er sam-

5 Jf. særudgaven "Mosque Conflicts in European Cities" i Journal of Ethnic and Migration Studies 31 (6) November 2005 (Cesari 2005).

6 Haderslevsagen indeholder de samme elementer som de øvrige moskébyggesager - en lokalt baseret modstand som bliver landspolitisk jf. "DF vil lave folkeafstemning, Skal Haderslev have en moske? Det vil Dansk Folkeparti give borgerne mulighed for at stemme om" Lokalavisen Haderslev (27. februar 2014); "Beskæmmede kirkefolk opfordrer byråd til at tillade moské" Kristeligt Dagblad (13. februar 2014); "Pengemangel sætter mosképrojekter i stå" Kristeligt Dagblad (23. januar 2014).

7 Ifølge fuldmægtig Klavs Bjerring fra Planstyrelsen, jf. BT 19. marts 1991 
men med demonstrationer også en del af modstandernes måde at manifestere en antimuslimsk fysikalitet. Et eksempel på hærværk er aktionen som den højreradikale organisation Danish Defence League gennemførte på Njalsgadegrunden i 2011, hvor de begravede et svin, der ifølge organisationen skulle 'forurene' grunden, så den ikke kunne benyttes til at bygge en moské. ${ }^{8}$

\section{Sai Baba og Arresødal}

Arresødal er en ejendom i Frederiksværk oprindeligt opført i 1788 i nyklassicistisk stil. Det var omdrejningspunktet i en konflikt, der i 2001-02 fik borgere og kommunalpolitikere i Frederiksværk på barrikaderne. Årsagen var, at Sai Bababevægelsen havde planer om at købe bygningen Arresødal af Kommunedata for at indrette en international højskole og religiøst center på stedet. Sai Baba-bevægelsens første leder Sathya Sai Baba (1926-2011) var, ifølge babaisterne, en reinkarnation af en fortidig Sai Baba ved navnet Shirdi Sai Baba (1838-1918) (Srinivas 2008, 23-48). Shirdi Sai Baba blev kendt som asket og forsøgte at forene forskellige religiøse opfattelser. Han bosatte sig, ifølge legenden, i en moské, som han sidenhen aldrig forlod. Denne Sai Baba hævdede også at være en inkarnation af Dattatreya, en semi-mytologisk brahmin, som blev betragtet som en avatarisk form af Vishnu. Sathya Sai Baba havde, ifølge den helgenlegende som han selv og hans følgere fortæller, været udsat for uforklarlige begivenheder siden hans barndom. Som 13-årig blev han bidt af en skorpion og var bevidstløs i flere uger efter. Da han vågnede fra sin koma, erklærede han, at han var inkarnationen af Sai Baba. Siden voksede gruppen af disciple til millioner verden over (ibid., 334-345). I Danmark har bevægelsen kun få tilhørere, ca. 70 ifølge formanden for Sai Baba Landsforeningen i Danmark, Stig Meincke. ${ }^{9}$

Ekstra Bladet var den første avis, der skrev om Sai Babas planer med Arresødal, og allerede i den første artikel blev indholdet for modstanden mod Sai Baba italesat af 1 . viceborgmester i Frederiksværk, Henry Larsen, som ville prøve at forhindre salget: “Jeg ved ikke, om guru-sekten er skyldig eller uskyldig i, hvad den anklages for [artiklen nævner, at Sai Baba "udnytter drenge og unge mænd seksuelt"]. Men tvivlen bør komme Frederiksværk og dets borgere til gode. Derfor foreslår jeg, at kommunen byder over og køber Arresødal, så vi ved, hvem vi får indenfor dørene." (Ekstra Bladet 1. okt. 2001). Modstanden mod Sai Babas planer om at etablere en højskole og et mødested for babaister fra hele Europa var altså udtalt helt fra starten, ikke mindst på grundlag af anklager om, at Sai Baba "udnytter drenge og unge mænd seksuelt". Om anklagerne mod Sai Baba var sande eller ej, eller om anklagen

8 Jf. "Højrefløj opruster: Begraver svin på moskegrund", Ekstra Bladet (18. november 2011). Eksempler på hærværk mod moskéer: "Nakskov får besøg af højreekstremister", TV2-Øst (8. december 2011); "Racistiske svin foran Aarhus moske i nat", P77, (29. januar 2012).

9 Jf. "Dansk Sai Baba-tilbeder: Hans død betyder intet", Politiken (24. april 2011). I en artikel om bevægelsen fra 1999 nævnes det, at Sai Baba har tiltrukket 500 faste medlemmer i Danmark (Pade 1999, 323). Det er generelt svært at finde pålidelig information om medlemstallet i nye religiøse bevægelser. 
mod guruen også inkluderede en pædofil praksis, som gjaldt alle babaister inklusiv de danske, var i denne sammenhæng ligegyldig. ${ }^{10}$ Anklagen mod Sai Baba var nok og smittede tilsyneladende af på resten af bevægelsens tilhørere. Det var dog først efter, at Danmarks Radio (DR) bragte en dokumentar om bevægelsen, at modstanden vandt større opbakning.

Pressen dækkede begivenhederne ivrigt, og 30. januar 2002 viste DR dokumentarudsendelsen Forført tilrettelagt af journalist Øjvind Kyrø. Den handlede om Sai Baba - om rygterne om at han havde sex med mindreårige, bedrageri, bagvaskelse, falske mirakler, magt og penge. Det var netop rygterne om Sai Babas seksuelle misbrug af mindreårige, som blev udgangspunktet for DR's planlagte nyhedsføljeton. Den startede med et indslag i morgenens P3 radioavis med et interview med journalisten bag programmet. Udsendelsen blev vist i den bedste sendetid onsdag aften, og efter programmet blev tv-avisen indledt med følgende proklamation af nyhedsværten Reimer Bo: “Overhovedet for den religiøse bevægelse [Sai Baba] beskyldes nu for omfattende seksuelt misbrug af sine tilhængere" (DR TV-Avisen 30. januar 2002). Indslaget i tv-avisen var dagens tophistorie, og i et længere indslag blev lederen af den europæiske Sai Baba-bevægelse interviewet. Dagen efter blev der fulgt op på udsendelsen med "nye" oplysninger i radioen og gæster i DR's 19-direkte. Historien blev iscenesat som relevant for politikerne. Frederiksværks borgmester, den socialdemokratiske Helge Friis blev spurgt om sin holdning til bevægelsen og udtalte til Ritzau, at kommunen hele tiden havde været skeptisk med hensyn til Sai Bababevægelsens indtog på Arresødal, men at kommunen ikke havde lovhjemmel til at afvise en uønsket køber, uanset om der var tale om Sai Baba, rockere eller nazister:

“Derfor kan jeg kun appellere til befolkningen om at reagere og stille sig selv det spørgsmål, om man virkelig ønsker en bevægelse med de anklager ind i vores område. Jeg har opbrugt mine muligheder som borgmester, men som menneske har jeg lov til at sige, at den slags ønsker jeg langt, langt væk både fra Frederiksværk og fra Danmark" (Ritzaus Bureau, 30. januar 2002).

Kirkeminister Tove Fergo fra Venstre blev også inddraget og måtte tage øjeblikkelig stilling til Sai Baba-bevægelsens status som godkendt trossamfund i Danmark: “Hvis jeg havde været kirkeminister dengang [Sai Baba blev godkendt som trossamfund], ville jeg ikke have anerkendt Sai Baba-bevægelsen. Det er min opfattelse, at man forvaltede meget liberalt. Min linie er nok mere strammerlinien", udtalte Tove Fergo til Ritzaus Bureau (31. januar 2002). ${ }^{11}$ Sai Baba kom på avisernes forsider, og som følge af rygterne om Sai Babas seksuelle misbrug blev spørgsmålet om Arresødal som et sted, hvor Sai Baba kunne udføre sine aktiviteter, en større sag i avi-

10 Anklager om pædofili, udnyttelse, bedrag, hjernevask osv. følger et ensartet mønster, som rettes mod mange nye religiøse bevægelser. For det meste er anklagerne falske og en måde at italesætte en modstand på overfor nye religiøse bevægelser (Hill, Hickman \& McLendon 2001). Sai Baba blev aldrig dømt for anklagerne, om end tidligere medlemmer af bevægelsen fortsat anklager ham for pædofili.

11 Bevægelsen blev godkendt som trossamfund under navnet Sathya Sai Baba i 1996 i henhold til Lov om xgteskabs indgåelse og opløsning (Familiestyrelsen/samliv/trossamfund.dk 2014). 
serne. I avis- og tv-indslag blev borgmester Helge Friis konfronteret med rygterne om bevægelsens guru. ${ }^{12}$ I alliance med den lokale formand for ældrerådet, den tidligere modstandsmand og folketingsmedlem for DKP og Fælles Kurs, Jørgen Tved blev der oprettede en folkekomité mod Sai Baba-bevægelsens tilstedeværelse i Frederiksværk. ${ }^{13}$ Der blev også organiseret en underskriftsindsamling, som 3.877 borgere skrev under på. ${ }^{14}$ Den lokale sognepræst arrangerede et møde, hvor næsten 100 mennesker kom for at høre en tidligere Sai-Baba tilhænger, nu kristen, Mette Grovermann, fortælle om sin tid i bevægelsen, og en storm af læserbreve blev bragt i de lokale aviser. ${ }^{15}$ Der var også planlagt et protestmøde med deltagelse af kirkeminister Tove Fergo og leder af Dialogcenteret Johannes Aagaard (1928-2007), men det blev ikke til noget, da Sai Baba-bevægelsen inden da trak købet af Arresødal tilbage. ${ }^{16}$ De massive protester materialiserede sig som underskrifter mod Sai Baba, læserbreve i aviser og protester i redaktionelle artikler. En manifest modstand, som talsmanden for Sai Baba i Danmark, Jørgen Trygved (1938-2006), tidligere direktør for Superfos, opfattede som en hetz, der umuliggjorde Sai Baba-bevægelsens tilstedeværelse i byen: "Der har været så meget hetz omkring projektet, at vi har været nødt til at overveje, om vi kan være bekendt at invitere udenlandske undervisere og elever til Frederiksværk" (Kristeligt Dagblad 3. april 2002). Protestbevægelsen i Frederiksværk formåede dermed at vinde den politiske dagsordenen i kommunen, således at det umuliggjorde Sai Baba-bevægelsens tilstedeværelse i byen og dermed legitimerede den politiske handlen i byrådet.

Med en lynaktion i byrådet lykkedes det med stor majoritet (kun én ud af 15 stemte imod), at lave lokalplanen om, så det ikke længere var muligt at bruge stedet til højskole. ${ }^{17}$ Hermed faldt grundlaget for Sai Baba-bevægelsens formål med at drive stedet bort. Kommunen købte herefter stedet, lavede igen lokalplanen om, og solgte slottet videre med et tab på en million $\mathrm{kr} .{ }^{18}$ Men pengene var givet godt ud, ifølge borgmesteren, for kommunen opnåede “... at holde en indisk sekt ude af Frederiksværk" (Politiken 25. november 2002). Jørgen Trygved udtalte til Ritzau, at:

Vi har set i øjnene, at vi må etablere os et andet sted. Vi kan ikke være bekendt at invitere udenlandske gæster hertil og risikere, at de bliver mødt med fjendtlighed. Der er in-

12 Der blev skrevet et større antal artikler om sagen i både lokale og landsdækkende aviser jf. f.eks. "Balladen om Sai Baba", Berlingske (9. januar 2002); "Borgmester opfordrer borgerne til at reagere mod Sai Baba", Ritzaus Bureau (30. januar 2002); "Sai Baba anklages for mafia-lignende virksomhed", Kristeligt Dagblad (12. februar 2002) og “En mio. kr. for at holde Sai Baba væk”, Politiken (25. november 2002).

13 Jf. f.eks. "Borgmester vil forsøge at samle lokal modstand", Ritzaus Bureau (31. januar 2002); "Modstand mod Sai Baba sekt", Jyllands-Posten (1.februar 2002); "1600 siger nej til Sai Baba", Kristeligt Dagblad (20. marts 2002).

14 Jf. "Palækøb: Kommune køber omstridt slot", Jyllands-Posten (18. april 2002).

15 “Tvivlen om Sai Baba”, Kristeligt Dagblad,( 9. februar 2002; 18. marts 2002); “En mio. kr. for at holde Sai Baba væk", Politiken (25. november 2002).

16 Jf. "Minister ville ikke have anerkendt Sai Baba som trossamfund", Ritzaus Bureau (31. januar 2002).

17 Jf. “Kommune vil købe Arresødal”, Ritzaus Bureau (3. oktober 2001).

18 Jf. "Frederiksværk vil købe og sælge slot", Jyllands-Posten (5. april 2002) og "Palækøb: Kommune køber omstridt slot", Jyllands-Posten (18. april 2002). 
gen bitterhed, kun en nøgtern vurdering af, hvad der er muligt og ikke muligt" (Ritzaus

Bureau, 2. april 2002).

Resultatet var, at den danske religionsmodels grænseflade blev bestemt af lokal protest og kommunalbestyrelsens plan om vedtagelse af en særlig lokalplan, der forhindrede Sai Baba i at etablere et religiøst sted for bevægelsen. Den offentlige forestilling om, hvad det hellige sted skulle og kunne indeholde, fungerede strukturerende for oplevelsen af det kommende religiøse center. Hermed blev lokalplanen det lokalpolitiske redskab, som udgrænsede en religiøs minoritets mulighed for at etablere et religiøst center, og mediernes repræsentation og lokale protester blev den benzin på bålet, som fik sagen til at udvikle sig. Kommunalbestyrelsen forbød ikke direkte Sai Baba-bevægelsen at købe Arresødal, men bidrog offentligt og ved hjælp af lokalplaner til, at bevægelsen ikke fik etableret et sted for deres aktiviteter. Dermed kan det diskuteres om det offentliges (byrådets) neutralitet i lokalplanssagen var til stede i kommunens sagsbehandling.

\section{Moskéen i Rovsingsgade}

Debatten om moskébyggeriet begyndte i marts 2012, hvor grunden blev købt af Dansk Islamisk Råd. ${ }^{19}$ Debatten har derfor hovedsaligt fundet sted efter moskébyggeriets begyndelse, og det har betydet, at debatten primært drejede sig om, hvad moskéens funktion kom til at være, dens finansieringsgrundlag, og hvilken betydning den ville få for muslimer i København og Danmark.

Moskébyggeriet på Rovsingsgade er en ombygning af en allerede eksisterende erhvervsejendom. Selve moskéen er i vestfløjen, mens der i den østvendte del af bygningen er indrettet et kulturhus. Det samlede bygningskompleks indeholder bl.a. mødelokaler, restaurant, fitnessrum, dagcenter for ældre, legeland til børn og kontorhotel for foreninger - i alt 6.800 kvadratmeter. Set udefra er det en hvid, let, minimalistisk dobbeltbygning i enkel skandinavisk stil, som næsten kunne være et almindeligt kontorhus, men den lave kuppel, minaret og de bueformede vinduer afslører, "at her åbner om kort tid Danmarks første 'rigtige' moské", som Politiken skrev. ${ }^{20}$ Den officielle åbning af moskéen, Hamad Bin Khalifa Civilisation Center, foregik i juni 2014.

I det officielle høringsmateriale beskrives byggeriet som “en arkitektur der danner bro mellem nordisk minimalisme og Mellemøstens islamiske hvidkalkede moskébyggerier." (Vingelodden 1 2012). I høringsmaterialet beskrives det også, hvordan moskéen kommer til at adskille sig fra traditionelle moskéer, idet der ikke vil blive kaldt til bøn fra den 20 meter høje minaret. Tårnet er "alene et visuelt tegn på byg- 
ningens anvendelse som muslimsk kulturhus med tilhørende moské" (idem). I høringsmaterialet gengives det, hvordan Den Københavnske Fond betinger sig, at der ikke vil "forekomme bønnekald og der vil blive udarbejdet en servitut herom som tinglyses på ejendommen" (idem). Det vil sige, at minareten mister sin traditionelle funktion som bønnekaldstårn og transformeres til et skulpturelt symbol på moskéen i en dansk kontekst. Minareter har i mange år været en vigtig del af symbolkampen mellem muslimer og antimuslimske kræfter ikke bare i Danmark, men i hele den vestlige verden (Saint-Blancat \& Friedberg 2005, 1083-1104; Jacobsen 2009). Det har bl.a. ført til et minaretforbud i Schweiz i 2009, efter en folkeafstemning afgjorde spørgsmålet (Baumann \& Tunger-Zanetti 2011, 152). Umiddelbart herefter stillede Dansk Folkeparti et beslutningsforslag i Folketinget om "afholdelse af vejledende folkeafstemning om forbud mod minareter" (Beslutningsforslag nr. B 104, 19. oktober 2010). Minareten og kuplen, repræsenterer vigtige arkitektoniske aspekter af moskéen, og dermed er lokalplanens tilladelse til Danmarks første minaret samtidig også en symbolsk anerkendelse af muslimers ret til hellige bygninger til religionsudøvelse i Danmark.

Dansk Islamisk Råd er en paraplyorganisation, som blev stiftet af ca. 30 muslimske foreninger i 2000. Den har ifølge flere avisers beskrivelser tilsammen ca. 25.000 medlemmer over hele landet. ${ }^{21}$ Der er typisk tale om et udvidet medlemsbegreb, som inkluderer brugere af moskéer, familiemedlemskaber etc. (Jacobsen 2013: 173-81). Dansk Islamisk Råd samler danske muslimer på tværs af etniske skel. Foreningen var med til at danne The Federation of Islamic Organizations in Europe, som har forbindelser til Det Muslimske Broderskab og politiske ledere i golfstaterne (Vidino 2005). Det har fået iagttagere til at regne Dansk Islamisk Råd for en konservativ organisation.22 Det afviser talsmanden for moskéen Mohamed Al Maimouni dog, ifølge Politiken: "Vi er moderate. Vi mener, Islam skal tilpasse sig det sted, man er, det er ikke det samme i Danmark som i Egypten. Vi er danske muslimer, og vi fokuserer på at være aktive, gode medborgere, som bidrager til samfundet" (Politiken 5. august 2013).

Det er ofte finansiering af moskébyggerier, som har sat en stopper for byggeplaner, men i Rovsinggades tilfælde havde Qatars afgåede emir, Hamad bin Khalifa alThani, sikret finansieringen. Emiren har betalt de 150 millioner kroner, byggeriet koster. Finansieringsgrundlaget har været stærkt omdiskuteret og er af medier og politikere fremhævet som et problematisk element ved byggeriet. ${ }^{23}$

Moskéen blev i den offentlige debat af kritikere først og fremmest associeret med en tolkning af islam, der potentielt fremmer muslimsk ekstremisme, islamisme og terrorisme, dvs. en sikkerhedspolitik diskurs, sekundært som en bygning der inde-

21 Se f.eks. "Dansk stormoské vil lave tv for terrorstyret kanal" Jyllands-Posten (5. september 2013).

22 Jf. f.eks. Pernille Bramming i Weekendavisen "Den sande islam" 10. august 2013); Bjørn Bredals leder i Politiken "Det er glædeligt, at Danmark omsider får en markant moske" (7. august 2013) og islamforsker Torben Rugberg Rasmussen i Politiken "Stormoske er skudt op i al stilhed" (4. august 2013).

23 Jf. f.eks. "Dansk Folkeparti vil granske ny stormoskes finanser", JyskeVestkysten (6. august 2013); "Stor ståhej om penge til stormoske", Jyllands-Posten (9. oktober 2013), og "Stormoské åbner under politiske protester", Berlingske (6. januar 2014). 
holder angreb på vestlige frihedsidealer på baggrund af en konservativ fortolkning af islam.

Moskeens angivelige konservative islamtolkning fik både kommunal- og landspolitikere til at klassificere moskéen som et sted, der kunne blive et arnested for radikalisering af muslimer. I første omgang var det Københavns Borgerrepræsentationsmedlemmer, som udtalte sig til medierne. Det socialdemokratiske medlem Lars Aslan Rasmussen udtalte til Berlingske, at "bag moskeen i Rovsingsgade er kræfter, som er endnu værre end det iranske præstestyre... [og at] Den slags gaver fra Qatar er ikke gratis, og jeg er bekymret for, at muslimer i Danmark risikerer at blive radikaliseret og skubbet endnu længere væk fra det samfund, som de skal være en del af" ("Stormoské i Nordvest bekymrer politisk", Berlingske 5. august 2013). I samme avis anførte Flemming Steen Munch, Venstres gruppeformand i Borgerrepræsentationen, betænkelighed ved oplysningerne om finansieringskilden: "Det er klart, at det sætter nogle tanker i gang, når Qatar, hvor islam praktiseres så rabiat, poster så mange penge i en moské i Danmark. Man kan frygte for radikalisering, og der bør holdes nøje øje med, hvad der kommer til at foregå i moskeen" (idem). Forløbet fik Dansk Folkepartis Borgerrepræsentationsmedlem Karin Storgaard til at kræve en redegørelse for byggeriet af Københavns Kommune. Hendes spørgsmål til Teknik- og Miljøforvaltningen (TMF) var bl.a. om “TMF har været vidende om, at det er regimet i Qatar, der har betalt denne moske, samt at Dansk Islamisk Råd, som hylder den rabiate egyptiske Iman al-Qaradawi, der står bag." (Teknik- og Miljøforvaltningen 2013). Storgaard ville endvidere gerne vide, hvilke muligheder Borgerrepræsentationen havde "for at gøre opmærksom på at det er under falske forudsætninger, der er sagt ja" (idem). Redegørelsen blev krævet på baggrund af oplysninger i en artikel i Ekstra Bladet den 11. august 2013 med titlen “Det muslimske broderskabs forlængede arm: Imam i ny moske hylder ekstremist". Notatet på én side blev sendt til Karin Storgaard den 3. september 2013, men indeholdt ingen omtale af Ekstra Bladets oplysninger. TMF slog fast at:

Motiverne og baggrunden for grundejerens ønske er forvaltningen uvedkommende, ligesom det heller ikke er et plan- eller byggesagsanliggende på hvilken måde en bebyggelse finansieres. Det er derfor sagsbehandlingen irrelevant at søge oplyst hvordan og hvem, der finansierer opførelse af en bebyggelse (ibid).

Resultatet af forvaltningens sagsbehandling var, at Teknik- og Miljøforvaltningen ikke fandt grundlag for at foretage sig yderligere i den anledning. Hermed blev lokalplanens neutralitet sikret af forvaltningens sagsbehandlere, som dermed blev religionsfrihedens grænsesættere i den aktuelle sag. 


\section{Helligsteder på grænsefladen}

De to cases analyseret i artiklen viser, hvordan forskellige lokale politiske myndigheder benytter lokalplaner til at grænsesætte religiøse samfunds bygninger i det offentlige rum. Dermed bliver lokalplaner til et af redskaberne for markeringen af religionsudøvelsens og dermed religionsfrihedens grænseflader i den danske religionsmodel. Religiøse organisationers byggeri i Danmark bestemmes i vid udstrækning af lokalplaner. Lokalplanerne vedtages i byråd inden for rammerne af planlovens bestemmelser og skal i princippet ikke diskriminere på reguleringsplanet. Det vil sige, at religiøse minoriteter skal behandles på samme måde som andre foreninger, institutioner og virksomheder.

De to eksempler viser, at lokalplaner kan benyttes som politisk redskab til at begrænse religionsudøvelse, og til at argumentere for en gældende lokalplansvedtagelses gennemførelse. I det første eksempel med Sai Baba-bevægelsens forsøg på at etablere et religiøst center i Frederiksværk blev lokalplanen brugt af kommunalpolitikerne til at forhindre bevægelsen i at gennemføre deres planer for etablering af en højskole og et uddannelsescenter. Lokalplanens neutralitet blev i dette tilfælde tilsidesat, da det var byrådets udtrykkelige hensigt, med borgmester Helge Friis i spidsen, at forhindre bevægelsen i at etablere sig i byen. ${ }^{24}$ For moskébyggeriet på Nørrebro i København var det anderledes, idet bygningen var under opførelse, og en lokalplan var ændret som følge af bygherrens visioner for byggeriet. Et flertal i Borgerrepræsentationen afviste at lade moskéens finansieringskilde have indflydelse på lokalplansprocessen. Resultatet var byggeriet af den første moské i Københavns Kommune. Bygningen er på en og samme tid et symbol på muslimers fysiske tilstedeværelse på Nørrebro og i Danmark og en anerkendelse af muslimers ret til religionsudøvelse i Danmark. Hermed er lokalplanen et redskab til virkeliggørelse af grundlovens princip om religiøse samfunds mulighed for at udøve deres religiøse praksis frit.

Lokalplansvedtagelser i kommuner kan altså virke to veje. Kommuner kan enten udgrænse religionsudøvelse som i Frederiksværks tilfælde, eller kommuner kan nægte at tage stilling til religionsindholdet for et lovligt trossamfund på baggrund af et argument om, at lokalplanen sikrer neutralitet og kun forholder sig til bygningens fysiske fremtoning, bygningsvedtægter m.m. Hermed er lokalplanen et vigtigt politisk redskab i udviklingen af den danske religiøse topografi, etableringen af helligsteder og muligheden for fri religionsudøvelse. Det er derfor nødvendigt med detaljerede studier af den politiske og forvaltningsmæssige beslutningsproces, når religiøse samfund ansøger om byggetilladelser, kræver ændringer af lokalplaner og interagerer med lokalbefolkningen i forbindelse med byggeplaner. 


\section{LITTERATUR}

Baumann, Andreas

2009 "Temples, Cupolas, Minarets: Public Space as Contested Terrain in Contemporary Switzerland", Religio 17 (2), 141-153.

Baumann, Andreas \& Andreas Tunger-Zanetti

2011 "Wenn Religionen Häuser bauen. Sakralbauten, Kontroversen und öffentlicher Raum in der Schweizer Demokratie", in: Martin Baumann \& Frank Neubert, eds., Religionspolitik - Öffentlichkeit Wissenschaft: Studien zur Neuformierung von Religion in der Gegenwart, Pano, Zürich, 151-188.

Bekendtgørelse af lov om planlægning

2013 Bekendtgørelse af lov om planlxgning, LBK nr. 587 af 27/05/2013.

Cesari, Jocelyne

2005 "Mosque Conflicts in European Cities: Introduction," Journal of Ethnic and Migration Studies 31 (6), November 2005, 1015-1024.

DISR

2013 Pressemeddelelse: Vedrørende: Fejlcitering af Dansk Islamisk Råd (DISR), Dansk Islamisk Råd, 06.09.2013, http://www.disr.info/vedrorende-fejlcitering-af-dansk-islamisk-rad-disr-omkring-2/?lang=da

Fenger, Ole

1989 Kirker rejses alle vegne 1050-1250. Gyldendal og Politikens Danmarks Historie, Bd. 4, Gyldendal, København.

Flyvbjerg, Bent

1991 Rationalitet og magt, bind 1 - Det konkretes videnskab, Akademisk Forlag, Aarhus.

Gieryn, Thomas F.

2000 "A Space for Place in Sociology," Annual Review of Sociology 2000 (26), 463-96.

Habraken, John N.

1998 The Structure of the Ordinary, Cambridge, London: MIT Press

Hill, Harvey, John Hickman \& Joel McLendon

2001 "Cults and Sects and Doomsday Groups, Oh My: Media Treatment of Religion on the Eve of the Millennium," Review of Religious Research 43 (1), 24-38.

Hvidovre Turistinformation

2013 "Nusrat Djahan Moské," http://www.oplev.hvidovre.dk/rundt-i-byen/kirkerne-og-moskeen/nusratdjahan-moske.aspx (set 13. 12. 2013).

Jacobsen, Brian A.

2013 "Muslimske grupper i Aarhus" in: L. Ahlin et al., eds., Religion i Aarhus 2013: En kortlægning af religion og spiritualitet, Center for Samtidsreligion, Aarhus Universitet, 174-181.

2011 "Kampen om stormoskéerne i København - religionssociologisk belyst", Kritik 201, 45-55.

2009 "Muslims on the Political Agenda", Nordic Journal of Religion and Society 22 (1), 15-35.

Jacobsen, Brian A. \& Willadsen, Katrine

2013 "Konfirmander giver kommunalpolitiske konflikter", Kronik, Kristeligt Dagblad, 09.09.2013.

Kold. Vibeke

1997 "En diskussion af casestudiets mulighed for at udvikle teorier om kønsarbejdsdeling og lige-stilling samt strategier for forandring af kønsrelationer", in: Center for Kvinde- og Kønsforskning/Varia 1.

Lov om planlægning

2013 Lov om planlægning.

Lægaard, Sune

2010 "Religiøse symboler, religionsfrihed og det offentlige rum: 'Stormoskeer' i København?" Tidsskriftet Politik 13, 6-14.

Morgan, David

2010 "Introduction: 'The Matter of Belief'" in: idem, ed., Religion and material culture: the matter of belief, 
Routledge, New York, 1-20.

Munk, Karen Pallesgaard

2008 "Når tilliden går tabt," magasinet Humaniora. 3:08, september 2008, 23. årgang, Forskningsrådet for Kultur og Kommunikation, 18-22.

Pade, Mikkel

1999 "Sathya Sai Baba" in: idem, Nye religiøse bevægelser i Danmark, Gyldendal, København, 322-341.

Rohe, Matthias

2012 "Germany", Yearbook of Muslims in Europe 4, 245-268.

Srinivas, Smriti

2008 In the Presence of Sai Baba: Body, City, and Memory in a Global Religious Movement, Numen Book Series, Volume 118, Brill, Leiden.

Teknik- og Miljøforvaltningen

2013 Notat vedr. Moskébyggeri på Rovsingsgade/Vingelodden, Sagsnr. 2013-0180594, Teknik- og Miljøforvaltningen Københavns Kommune.

Vidino, Lorenzo

2005 "The Muslim Brotherhood's Conquest of Europe", Middle East Quarterly, Winter 2005, 25-34.

Vingelodden 1

2012 Opførelse af minaret på matr. nr. 6204, Udenbys Klædebo Kvarter. Naboorientering vedrørende dispensation fra lokalplan nr. 276 Rovsingsgade Marts 2012.

Østergaard, Jesper

2006 “'Sted' og 'rum' som analytiske begreber i religionsvidenskaben", Totem. Tidsskrift ved Afdeling for Religionsvidenskab, Aarhus Universitet, 5-56.

Brian Arly Jacobsen, adjunkt, ph.d. Institut for Tværkulturelle og Regionale Studier, Københavns Universitet 
